\title{
Utilization of the Internet as Media for Marketing SMEs Products
}

\author{
Sony Hendra Permana ${ }^{1,{ }^{*}}$ Edmira Rivani ${ }^{1}$ Eka Budiyanti ${ }^{1}$ \\ ${ }^{1}$ Research Center Expertise Body of Indonesian House of Representative \\ *Corresponding author. Email: sony.hendra@gmail.com
}

\begin{abstract}
One of the main problems faced by Small and Medium Enterprises (SMEs) is the problem of marketing. However in the current era of the Industrial Revolution 4.0, marketing should not be a problem anymore. SMEs can utilize the internet to solve their marketing problem. This paper aims to describe how to utilize the internet as medium for marketing SMEs products. This paper is descriptive by using a qualitative approach. The results of the study reveal that the internet can open access for SMEs to marketing their product at a low cost and reach a wide market. First, SMEs can create a website about their business and products through website creation service providers. Second, SMEs can also use social media as their marketing channel. SMEs can utilize then business platform in social media such as Facebook fo Business, Google My Business, and Instagram for Business as marketing media. Third, SMEs can utilize e-commerce, which has rapidly increased in Indonesia. There are several forms of e-commerce in Indonesia, such as classified ads, retailers, and marketplace websites. All these marketing media will greatly help the SMEs in the marketing process because they are connected to a wide range of market by the internet and are not limited to space.
\end{abstract}

Keywords: SMEs, marketing, internet, social media, e-commerce.

\section{INTRODUCTION}

In the past few decades, the usage of the internet has increased very rapidly. The internet, which was originally only used as an electronic information exchange tool, now has turned into a tool for business strategy applications such as marketing, sales, and customer service [1]. Furthermore, the rapid development of information technology and the internet has also led to a 4.0 industrial revolution, which is characterized by increasing connectivity, interaction, and boundaries between humans, machines, and other increasingly converging resources through the technology information and communication [2]. In this era of Industrial Revolution 4.0, all processes are carried out with an automation system in all activation processes, where internet technology functioned as the driving force.
In Indonesia, the development of the internet is quite fast. Initially, the internet was only developed in public universities in the early 1980s, but now it had spread to most of the population. Based on data from the Indonesian Internet Service Providers Association (APJII), at the end of 2014, the number of internet users in Indonesia had reached 88.1 million. This shows that 34.9 percent of the population in Indonesia has accessed the internet [3]. Java and Sumatra islands are the regions with the largest population accessing the internet, which is 52 million people in Java and 18.6 million people in Sumatera. Meanwhile for other regions the number of internet users are still very low, which are 4.2 million people in Borneo, 7.3 million people in Sulawesi, and 5.9 million people in Papua.

For the economy of Indonesia, the growth of the internet has actually had a quite positive impact because it can create new types of businesses. According to research from the International Telecommunication 
Union in 2011 summarized in McKinsey, the development of Information and Communication Technology (ICT), which is refered to the development of the internet, has had a positive impact on the economy of a country. In this report, it was stated that every 10 percent increase in broadband network penetration had a positive impact on GDP growth of 1.21 to 1.38 percent [4]. In Indonesia, various new internet-based businesses began to emerge recently. One that is quite phenomenal is Go-jek. This Information Technology enterprise based in the transportation sector has changed the transportation industry, especially public transportation in Indonesia.

As for micro, small and medium-sized enterprises (SMEs), the fast development of internet is a chance to overcome the main obstacle for them i.e., marketing problem. Based on the results from a research collaboration had been conducted by the Ministry of

\section{LITERATURE REVIEW}

\section{Online Marketing}

In this era, SMEs can do online marketing their product through the internet. SMEs could introduce their brand or product (brand awareness), which is known as the brand endorsement technique. The brand endorsement is a persuasive communication strategy used by brand owners or businesses by appointing someone to introduce their products and services. The endorsement brand aims to strengthen the community's perceptions about the superiority of a product so they can be persuaded to buy the product [7].

The easiest brand endorsement which can be done by the SMEs through social media is by collaborating with celebrities or often also known as celebrity endorsement. With this technique, the celebrity will present and use the products of SMEs on their social media accounts because oftentimes, the celebrity social media has many followers who have a tendency to follow those celebrity's lifestyle. The intended celebrities are not only celebrities who often appear on television or magazines but also ordinary people who have numerous followers on social media, which are called social media celebrities or celebrities.

The communication strategies in order to develop brand awareness through celebrity endorsement are able to emotionally influence the consumers so that they can increase product sales [7]. This is because social media will reach 2 types of customers: first, customers in active shopping conditions, who will seek as much information as possible to help them to decide on shopping. Second, customers in passive shopping conditions, who will get a stimulus from promotions carried out by SMEs, family,
Cooperation and Small, Medium Enterprise with the Indonesia Bureau of Statistics, it stated that marketing $(34.75 \%)$ is the main problem faced by the micro, small and medium enterprise after the funding problem $(51.09 \%)$. Besides, the other problems are the raw material $(8.59 \%)$, labor $(1.09 \%)$, logistics $(0.22 \%)$, and others $(3.93 \%)[5]$.

Unfortunately, SMEs have not yet used the development of the internet to address this marketing problems. Only 9 percent of SMEs have advanced online business capabilities by utilizing e-commerce as their marketing media, and 18 percent of SMEs have intermediate online business capabilities where they use the web or social media as their marketing media [6]. For this reason, this article will discuss how to utilize the internet as a media for marketing SMEs Products in Industrial Revolution 4.0 Era.

friends, or other online communities and becoming active shopping [8]. Thus, this method can be considered as a fairly effective marketing method besides marketing methods through other media

\section{E-commerce in Indonesia}

Currently, e-commerce in Indonesia is rapidly developed. Even, Indonesia is named as one of the countries with the largest e-commerce market growth in the world i.e., 17 percent per year. This is believed to be supported by the growth of the middle class in Indonesia, which is quite high. Even the Boston Consulting Group predicts that by 2020 Indonesia's middle population will reach around 141 million. The high number of the middle class and its high purchasing power is a potential market for e-commerce companies to develop.

As for the consumers or the public, the presence of ecommerce will provide benefits, namely, consumers can immediately see the products offered by SMEs online. In addition, it will also simplify and accelerate the process of product purchasing transactions [9]. While for SMEs, e-commerce can provide flexibility in production, delivery processes and receive product offerings quickly and economically, provide speed in sending to customers, and support the paperless transaction [10]. However, the most important benefit that can be obtained by SMEs from e-commerce is the expansion of the market because of the broad coverage of e-commerce. E-commerce can be reached by anyone, anytime, and anywhere as long as consumers are connected to the internet. 


\section{METHODOLOGY}

This paper is descriptive by using a qualitative approach. Data is collected through books, research reports, the internet, and journals. Besides that, interviews with informants were also conducted as confirmation of the research findings. The informants in this study were SMEs who had used the internet as a medium for marketing their product. The determination of informants was done with purposive techniques, especially convenience and judgment, which means that the researchers themselves determine someone to be determined as an informant, with due to comfort during interviews. Concepts and theories are used as supporters, which are considered relevant.

\section{RESULTS AND ANALYSIS}

\section{Creating a Business Website or Trademark}

Having a website for SMEs perpetrators is very important in order to offer their products through internet media. The definition of the website itself is a media or place that allows a user to express himself, his hobbies, knowledge, the products he sells, and any information that can be accommodated by text, images, videos, animations, and other multimedia files [11]. The website can be used as first, electronic brochure that can be accessed from all corners of the world for 24 hours. Secondly, it becomes a virtual market where global buyers and sellers meet [11]. Thus, the existence of a website for SMEs will become very helpful in terms of opening up marketing access or assisting in selling products.

The existence of SMEs that owned a website shows that the business that is owned by SMEs does exist. The website can also be used as an official identity for the owner who explains more detail about the business profile, characteristics, and benefits of the product, and others. Thus, the website is expected to be able to grow the awareness of its readers in the presence of an organization, a particular product, or brand. The benefits that can be obtained by creating a website for SMEs are selling their products, introducing the SMEs profile to the world who accesses that website, and publication media to publish and promote their products [12].

Making a simple website for SMEs is very easy. Currently, there are quite a number of free website hosting service providers so that everyone can create their own website [11]. One of them that has been widely used is Wordpress.com. Wordpress.com is a blog-type website creation service provider which is commonly referred to as blog hosting [11]. The SMEs only need to have an email in order to create a website of this type of blog. The way to make it is also relatively easy, just go to the www.wordpress.com page so users will be offered automatically to create an account. The steps for creating a website are also relatively short with a clear guideline. Users can decide to use either the free or paid website version. It depends on the needs of the user. To enhance the appearance of the website, users can use special themes for online stores that are widely available on the internet, both paid and free. In addition, to facilitate buying and selling activities on the website, users also need to install several plugins.

\section{Utilization of the Social Media}

Currently, social media is one of the needs of millennial society. Social media is a medium that can be used to socialize both personally and in a group between online users. At present, Indonesia is one of the countries with the largest social media users in the world. Based on the Tetra Pak Index 2017 report, there are around 132 million internet users in Indonesia, but around $40 \%$ are social media enthusiasts. The report also stated that more than 106 million Indonesian people use social media every month, whereas 85 percent using mobile devices to access their social media [13]. The access to huge social media through mobile devices is in line with the rapid growth of smartphones in Indonesia as the fourth largest population of active smartphone users country in the world after China, India, and the United States. Based on these data, this is a huge opportunity for SMEs to utilize the numerous social media users as their marketing target. The most popular social media in Indonesia nowadays is Facebook, Google+, Twitter, Instagram, and Pinterest, with 15, 12, 11, 10, and 7\% proportion of users, respectively [14]. The SMEs can create accounts on social media and make use of the marketing features available on social media. Thus SMEs can conduct trading activities through these media.

Thanks to its business feature, Facebook became social media with the most users in Indonesia. By using this feature, users can advertise their products to highly potential market, 1.4 billion and more than 2 billion people are using Facebook daily and monthly, respectively, and more than 6 million active advertisers on Facebook. Due to its broad coverage, more people will be well informed regarding the SMEs and their businesses. With this huge market reach, it can make many people know about the existence of SMEs and their businesses, which alleviates the selling opportunity.

Utilizing Facebook as a marketing medium, SMEs can enjoy several benefits. First, providing information functions. In the Facebook application, there is a column 
containing various user information, such as age, location, activities, and other information, which will be needed to determine the market segmentation that will be targeted by business stakeholders during marketing activities. Second, more focused market segmentation because filtering out the targeted market can be carried out in accordance with the information submitted by Facebook users. Third, the ability to be accessed at any time either by using a personal computer or a smartphone, as long as it has an internet connection. Fourth, the ease of communication which users can communicate with each other using feature message and chat on the Facebook application. Fifth, zero time feedback. The feedback of the purchased products, both criticism and suggestion can be instantly delivered. Sixth, always connected, the marketing activities can be performed at any time as long as Facebook stands. Seventh, low budget high impact. Utilizing Facebook as a marketing medium does not need the cost, but its impact can be effectively targeted to the readers. Eighth, new wave marketing because Facebook is one of the main causes of the changes in the marketing world [15].

Besides Facebook, Google is also issued the Google My Business platform which is connected to Google+ and is useful to maximize the business potential of SMEs. In Google business platform features there are very helpful for businesses in marketing their products. The features that can support business activities are: first, physical location. Through this feature, the customer can find out the seller's business location because it is connected to Google Maps. Second, Service Area. In this feature, SMEs can have messaging services between or services that can be brought to the order location. Third, Brand Categorization. In this feature, users can easily search for products because they have been categorized. For SMEs with the Google My Business platform, it will provide various benefits, namely getting promoted by Google Maps, Google My Business manages working hours online, gets reviews about SMEs, increases SMEs website on Google search, and increases business value. It is because those businesses registered in Google My Business has a good reputation [16].

Another social media which is currently also being used as an online marketing media is Instagram. Instagram is an application that serves to share photos and videos. With this function, Instagram has various benefits for SMEs actor to build and develop their brands or products. Instagram has also launched Instagram for Business, which provides services to create a business profile for free. The most excellent feature in Instagram compared to other platforms is the Insights feature. This feature helps the stakeholders by providing important information about their followers and the posting, which could widely spread out. With this information, businessmen are able to find out the behavior and demographic of their target market. In addition, Instagram also has a Promote feature, which allows businesses to make their posts as ads in the Instagram application and choose their target audience [17].

Apart from the three social media have been mentioned above, there are many more social media that can be utilized by SMEs to expand their marketing access, such as Twitter, YouTube, and others. By using social media, the SMEs could also introduce their brand or product (brand awareness), which is known as the brand endorsement technique.

\section{Utilizing an E-Commerce}

Another internet-based marketing media that can be utilized by SME stakeholders is through e-commerce. Currently, the in-person meeting between the seller and buyer is no longer needed for the buying and selling process, but it can be anywhere by using the internet. With the fast development of the internet nowadays, many online shopping sites (e-commerce) have sprung up in order to make buying and selling activities easier. Ecommerce is a system that changes the traditional trade paradigm, which requires sellers and buyers to meet directly in a certain place become an electronic commerce trading system by utilizing the advances in information technology or the internet [9].

The first e-commerce model that can be utilized by SMEs is e-commerce that provides services to advertise for free. This e-commerce model is generally referred to as classified ad websites. In this model, the seller conducts free advertising activities on the website. At the same time, the buyer can see the various choices of product categories that he is looking for from various sellers. However, for sale-purchase transactions, sellers and buyers must communicate directly. Currently, the most famous and widely used of this e-commerce model in Indonesia is OLX.com.

When the SMEs businessmen do not conduct a direct transaction with the buyers, they can utilize the ecommerce model with a retailer system. In this model,the process of buying, selling, and stocking the products can be done by e-commerce companies through the system they have built. The e-commerce companies will get a supply of products from various SMEs, through consignment systems and direct purchases. Mostly, the ecommerce companies will get a number of margins or sales discounts from the bigger players before they sell it 
to the consumers. In Indonesia, there are quite a number of e-commerce companies such as Blibli.com, berrybenka.com, lazada.com, etc.

The other options of the e-commerce models that can be used by the SMEs is providing buying and selling services directly to online sites or act as online mall service providers, but the buying and selling activities and inventory management are carried out by the seller. The SMEs can register as a seller member, then buying and selling activities are carried out on the site. This ecommerce model is known as marketplaces. In order to ensure consumer safety from fraudulent attempts by individuals, and also to ensure that the SMEs provide good sales services, oftentimes, the e-commerce companies provide a centralized payment system to the e-commerce company accounts as joint accounts for sellers who are registered or called escrow. After the product is received by the consumer, then the ecommerce company will forward the payment to the seller. In Indonesia, a great deal number of e-commerce is this company models, but the most market share is dominated by Bukalapak and Tokopedia.

\section{CONCLUSION \& RECOMMENDATION}

One of the problems that oftentimes faced by SMEs is marketing. Commonly, they can only produce products but getting confused about marketing their products. However, with the development of the internet nowadays, these problems actually are having some alternative solutions. The SMEs can open up access to marketing cheaply and have a wide range of coverage by using the internet. First, the SMEs can create a website about their business and products through hosted website creation service providers. Making this website can also be adjusted to the needs of business actors by using either a paid or free website. Second, the SMEs can also utilize social media as their marketing channel. Its broad reach, and also they have a business platform can be used as a marketing medium for free. Third, the SMEs can also take advantage of the rapid development of e-commerce nowadays in the form of classified ads, retailers, marketplace websites. All these marketing channels will greatly help the marketing process for SMEs because they have a wide range and are limitless in terms of space and time.

In order for SMEs to utilize the internet as a media for marketing their products, SMEs must increase their capacity of knowledge in the field of information technology. SMEs must change their mindset that social media is not just a friendship network but is a potential market for their products. Meanwhile, the government also needs to increase internet access and speed evenly throughout Indonesia so that SMEs in every region can have the same opportunity to utilizing the internet as media for marketing their products.

\section{AUTHORS' CONTRIBUTIONS}

Sony Hendra Permana, Edmira Rivani, and Eka Budiyanti contributed to the design and implementation of the research, to the analysis of the results, and to the writing of the manuscript.

\section{REFERENCES}

[1] O. Y. Yuliana, "Penggunaan Teknologi Internet Dalam Bisnis", Jurnal Akuntansi \& Keuangan, 2 (1), pp. 36-52, 2000. DOI https://doi.org/10.9744/jak.2.1.pp.\%2036-52

[2] Kementerian Perindustrian. "Making Indonesia 4.0: Strategi RI Masuki Revolusi Industri Ke-4". manufacturingindonesia.com.

https://manufacturingindonesia.com/makingindonesia-4-0-strategi-ri-masuki-revolusi-industrike-4/ (accessed September 7, 2018)

[3] Asosiasi Penyedia Jasa Internet Indonesia (APJII), Profil Pengguna Internet Indonesia 2014. Jakarta: Asosiasi Penyedia Jasa Internet Indonesia, 2015.

[4] M. Gryseels, N. Manuel, L. Salazar, dan P. Wibowo, Sepuluh Gagasan Untuk Memaksimalkan Dampak Sosio-Ekonomi TIK di Indonesia. Jakarta: McKensey \& Company, 2015.

[5] S. Sulaeman, "Pengembangan Usaha Kecil dan Menengah dalam Menghadapi Pasar Regional dan Global", Infokop, Nomor 25 Tahun XX, 2004.

[6] S. Deny. "Baru 9 Persen UMKM RI yang Masuk ECommerce". Liputan6.com. https://www.liputan6.com/bisnis/read/3582327/bar u-9-persen-umkm-ri-yang-masuk-e-commerce (accessed March 10, 2018).

[7] M. Roll, Asian Brand Strategy, New York: Palgrave Macmillan, 2006.

[8] L. Moriansyah, "Pemasaran Melalui Media Sosial: Antecedents dan Consequences", Jurnal Penelitian Komunikasi dan Opini Publik, 19 (3), pp. 187-196, 2015.

[9] S. Haryati \& T. Irianto, "Rancang Bangun Sistem Informasi E-Commerce Untuk Usaha Fashion Studi Kasus Omah Mode Kudus", Journal Sentra Penelitian Engineering dan Edukasi, 3 (1), pp. 8-14, 2011.

DOI:

http://dx.doi.org/10.3112/speed.v3i1.889

[10] A. Adiono, "Peran E-commerce Untuk Meningkatkan Daya Saing UKM". Academia.edu. https://www.academia.edu/5629621/PERAN_E- 
COMMERCE_UNTUK_MENINGKATKAN_DA YA_SAING_UKM_-

_Agung_Adiono?auto=download (accessed Juli 14, 2016).

[11] A. Zaki dan SmitDev Community, Kiat Jitu Membuat Website Tanpa Modal, Jakarta: PT. Elexmedia Komputindo, 2009.

[12] R. Rachmanto, 9 Langkah Praktis Membuat Website Gratis, Jakarta: PT. Elexmedia Komputindo, 2017.

[13] Yudhianto, "132 Juta Pengguna Internet Indonesia, 40 Penggila Medsos". Detik.com. https://inet.detik.com/cyberlife/d-3659956/132juta-pengguna-internet-indonesia-40-penggilamedsos (accessed September 15, 2018).
[14] Y. Ramadhani, "Mengapa Media Sosial Jadi Sarana Menjual Produk?". Tirto.id. https://tirto.id/mengapa-media-sosial-jadi-saranamenjual-produk-cu46 (accessed September 8, 2018).

[15] Z. Muttaqin, "Facebook Marketing Dalam Komunikasi Pemasaran Modern", Teknologi, 1 (2), pp. 103-109, 2011.

[16] Anonim, "Tingkatkan Bisnis Anda Melalui Google Bisnisku (Google My Business)". Goukm.id. http://goukm.id/google-bisnisku-google-mybusiness/ (accessed September 12, 2018).

[17] Natasya, "12 Tips dan Strategi Marketing Instagram Untuk Bisnis Anda". Dewaweb.com. https://www.dewaweb.com/blog/tips-dan-strategimarketing-instagram-untuk-bisnis-anda/ (accessed September 15, 2018). 